\title{
Determination of Nutrient Contents in the Leaf Litter of Diospyros crassiflora S. (Hiern-FWTA) Plantation in Okwuta-Ibeku, Umuahia, Abia State, Nigeria
}

\author{
Bruno Iniobong Nsien1, Eric Etim Offiong², Pretty Henry Dan1, Esther Ewongoabasi Eric1 \\ ${ }^{1}$ Forestry Research Institute of Nigeria, Ibadan, Nigeria \\ ${ }^{2}$ Department of Forestry and Wildlife Resources Management, University of Calabar, Calabar, Nigeria \\ Email: inibruno@yahoo.com, ericoff07@gmail.com
}

How to cite this paper: Nsien, B. I., Offiong, E. E., Dan, P. H., \& Eric, E. E. (2022). Determination of Nutrient Contents in the Leaf Litter of Diospyros crassiflora S. (HiernFWTA) Plantation in Okwuta-Ibeku, Umuahia, Abia State, Nigeria. Open Journal of Forestry, 12, 162-176.

https://doi.org/10.4236/ojf.2022.121009

Received: August 16, 2021

Accepted: January 26, 2022

Published: January 29, 2022

Copyright $\odot 2022$ by author(s) and Scientific Research Publishing Inc. This work is licensed under the Creative Commons Attribution International License (CC BY 4.0).

http://creativecommons.org/licenses/by/4.0/

(c) (i) Open Access

\begin{abstract}
Determination of nutrient contents in Diospyros crassiflora leaf litter was carried out in the Forestry Research Institute of Nigeria (FRIN), Okwuta-Ibeku, Umuahia, Abia State, Nigeria in 2016 and 2017. Three $1 \mathrm{~m} \times 1 \mathrm{~m}$ trays were randomly positioned for collection of leaf litter production from $4 / 5$ years old Diospyros crassiflora species in each block $(10 \mathrm{~m} \times 25 \mathrm{~m})$ within the plantation totaling 1.5 ha. A Randomised Complete Block Design (RCBD) with three replicates was used to study the mean monthly leaf litterfall of Diospyros crassiflora. Leaf litter was collected from each of the three litter trays per block and placed in paper bags every $28^{\text {th }}$ day of each month from January-December in 2016 and in 2017. Fifteen grammes (15 g) of properly mixed and oven-dried samples of $D$. crassiflora leaf litter were milled and sieved in 1 $\mathrm{mm}$ sieve; $0.3 \mathrm{~g}$ was used to determine nutrient elements and their concentrations. The data obtained from mineral nutrient contents of $D$. crassiflora leaf litter was analysed using analysis of variance. Result reveals the mean concentrations of nitrogen (1.41 and $\left.1.41 \mathrm{mg} \cdot \mathrm{l}^{-1}\right)$, phosphorus $(0.18$ and 0.18 $\left.\mathrm{mg} \cdot \mathrm{l}^{-1}\right)$, potassium $\left(0.68\right.$ and $\left.0.68 \mathrm{mg} \cdot \mathrm{l}^{-1}\right)$, sodium $\left(0.35\right.$ and $\left.0.30 \mathrm{mg} \cdot \mathrm{l}^{-1}\right)$, calcium (1.57 and $\left.1.56 \mathrm{mg} \cdot \mathrm{l}^{-1}\right)$, magnesium $\left(0.32\right.$ and $\left.0.31 \mathrm{mg} \cdot \mathrm{l}^{-1}\right)$, chlorine $(0.25$ and $\left.0.24 \mathrm{mg} \cdot \mathrm{l}^{-1}\right)$, Organic carbon $\left(0.03\right.$ and $\left.0.03 \mathrm{mg} \cdot \mathrm{l}^{-1}\right)$ and Organic matter (1.17 and $1.18 \mathrm{mg} \cdot \mathrm{l}^{-1}$ ) etc. in D. crassiflora leaf litter in January-December (2016 and 2017). The study shows almost uniform distribution of mineral elements concentrations in 2016 and 2017.
\end{abstract}

\section{Keywords}

Diospyros crassiflora, Plantation, Leaf Litter, Nutrient Elements, 


\section{Introduction}

The forest trees and shrubs, especially foliar components are utilized by animals (livestocks) as fodder (Longman, 2007). Most of these tree species comprise of proteins, mineral nutrients and vitamins, which nutrient contents also vary from species to species (Dicko and Sikena, 1992). The variation in nutrient (N, P, and $\mathrm{K})$ concentrations in the litter of different species at the initial stages of decomposition is due to different families with variations in chemical and biochemical properties of leaf litters (Hasanuzzaman and Hossain, 2014). Tree species affect soil chemical and biological properties through many factors, such as the rates and distribution of nutrient and water inputs, outputs and cycling (Binkley and Giardina, 1998).

Tree species influence soil chemical properties through differences in the quantity and chemistry of their leaf litterfall (Guckland et al., 2009; Reich et al., 2005; Vesterdal et al., 2008 and Mangesh et al., 2019). According to Hasanuzzaman and Hossain (2014), nutrient concentration was found to decrease gradually at the end of a 180 days' experiment in dry season on Common Horticultural Cropland Agroforest Tree Species of Bangladesh. Conversely, nutrient concentrations decreased at the initial stage but increased at the end of the study in the raining season.

The nutrient content of soil such as available Nitrogen (Av. N), Organic Carbon (OC \%), available Phosphorous (Av. P) and exchangeable Potassium (K) showed decreasing nutrient content with depth (Mangesh et al., 2019). Kumar et al. (2012) reported nitrogen, phosphorus contents and nitrogen mineralization of soil nutrients were related to litter nutrient release, but studies have shown that the impact of nutrient supply on litter substrate quality is unpredictable, because the internal nutrient concentration in live leaves and aging leaves absorb different nutrients, litter leaf nutrient leaching, and species with high nutrient content accompanied soil nutrient cycling. This implies that plant species, age and substrate quality has vital role to play in nutrient contents of leaf litter deposited in the soil in a given ecosystem. Leaf litter of selected plant species significantly contributed towards soil nutrient status (Mangesh et al., 2019).

Nitrogen and phosphorus concentrations and remaining stocks from decomposing leaf litter were consistently higher in Carpinus litter than in Quercus litter, thus calcium and magnesium concentrations which remain intact from decomposing litter varied considerably among the three litter types because these elements were dependent on inherent characteristics of leaf litter rather than on immobilization or on leaching during the decomposition processes (Jeong et al., 2015).

However, most leaf litters contain adequate levels of mineral content which 
include calcium $(\mathrm{Ca})$, magnesium $(\mathrm{Mg})$, manganese $(\mathrm{Mn})$, potassium $(\mathrm{K})$, phosphorus ( $\mathrm{P})$ etc., while some have higher concentrations of calcium and potassium than the other minerals (Dicko and Sikena, 1992). There are also abnormal concentrations of some minerals, such as sodium chloride and seleniums, in some browse plants (Wood, 1995 and Longman, 2007). Cycling of N, P, K, Ca and $\mathrm{Mg}$ which are soil derived nutrient elements can also limit primary production; these nutrient elements are themselves influenced by climate, species composition and successional status (Ananthakrishnan, 1996). The concentrations of $\mathrm{N}, \mathrm{P}, \mathrm{K}, \mathrm{Ca}$ and $\mathrm{Mg}$ in foliage may also vary with the type of soil (Ananthakrishnan, 1996). This paper focuses on determination of nutrient contents in the leaf litter of Diospyros crassiflora (African Ebony) plantation in Umuahia, Abia State in 2016 and 2017.

\section{Materials and Methods}

\subsection{Description of Study Sites}

The study of determination of nutrient contents in the leaf litter of Diospyros crassiflora (African Ebony) was carried out in Humid Forest Research Station, Forestry Research Institute of Nigeria (FRIN), Okwuta-Ibeku, Umuahia, Abia State, Nigeria. Okwuta-Ibeku, Umuahia is located at kilometres five ( $\mathrm{km} \mathrm{5)}$ along the Umuahia/Ikot Ekpene highway. It is within the lowland rainforest (Keay, 1959). It lies between longitudes $7^{\circ} 32^{\prime}$ and $8^{\circ} 10^{\prime} \mathrm{E}$ and latitude $5^{\circ} 29^{\prime}$ and $6^{\circ} 14^{\prime} \mathrm{N}$ of the equator, and on an altitude of $122 \mathrm{~m}$ (Source: Metrological Station, National Root Crop Research Institute (NRCRI) Umudike, Nigeria). The soil type is Ultisol which ranges from sandy loam to sandy clay-loam (Source: Soil Division, NRCRI, and Umudike). Umuahia has the following mean annual climatic data: rainfall: $2238 \mathrm{~mm}$, maximum and minimum temperatures: $32^{\circ} \mathrm{C}$ and $23^{\circ} \mathrm{C}$ respectively, and relative humidity: 65\% - 80\% (Source: Metrological Station, NRCRI, Umudike, Nigeria). The vegetation of the study site within the Humid Forest Research Station, according to Ariwaodo (2017) has the following plant species: Bambusa vulgaris (Poaceae), Milletia aboensis (Papilonaceae), Rauvolphia vomitoria (Apocynaceae), Tabernaemontata pachysiphon (Apocynaceae), Elaeis guineensis (Arecaeae), Alcornea cordifolia (Euphurbiaceae), Anthoncliesta djalonensis (Loganiaceae), Mallotus oppositifiolius (Euphorbiaceae), Antiaris africana (Moraceae), Combretum spp (Combretaceae), Lonchocarpus cyanescens (Loganiaceae), Palisota hirsute (Commelianaceae), Massularia acumminata (Rubiaceae), Macaranga barteri (Euphorbiaceae), Dalbergia melanoxylon (Papilonaceae), Melicia excelsa (Meliaceae), Entandrophragma angolense (Meliaceae) and Carpolubia lutea (Polygalaceae).

\subsection{Methods}

\subsubsection{Experimental Design}

A Randomised Complete Block Design (RCBD) with three replicates was used to study the mean monthly leaf litterfall of Diospyros crassiflora. Three $1 \mathrm{~m} \times 1 \mathrm{~m}$ 
trays were randomly positioned for collection of leaf litter production from $4 / 5$ years old Diospyros crassiflora species in each block $(10 \mathrm{~m} \times 25 \mathrm{~m})$ within the plantation.

\subsubsection{Data Collection and Laboratory Analysis}

Leaf litter was collected from each of the three litter trays per block and placed in paper bags every $28^{\text {th }}$ day of each month from January-December in 2016 and in 2017. The monthly collected leaf litter was oven-dried at $70^{\circ} \mathrm{C}$ for 48 hours at the Laboratory of the Department of Forestry and Environmental Management, Michael Okpara University of Agriculture, Umudike, Abia State, Nigeria. The oven-dried leaf litters per litter tray were weighed to obtain the total litter production each month.

Fifteen grammes ( $15 \mathrm{~g}$ ) of properly mixed and oven-dried samples of $D$. crassiflora leaf litter were milled and sieved in $1 \mathrm{~mm}$ sieve. From the oven-dried milled samples, $0.3 \mathrm{~g}$ was used to determine: nitrogen $(\mathrm{N})$, phosphorus $(\mathrm{P})$, potassium $(\mathrm{K})$, sodium $(\mathrm{Na})$, calcium $(\mathrm{Ca})$, magnesium $(\mathrm{Mg})$, chlorine $(\mathrm{Cl})$, Iron $(\mathrm{Fe})$, hydrogen ion concentration $(\mathrm{pH})$, cadmium $(\mathrm{Cd})$, lead $(\mathrm{Pb})$, Organic carbon and Organic matter. The sub-sample of $D$. crassiflora was digested for total $\mathrm{N}$ by the micro-Kjeldahl method (Jackson, 1962). Total P was determined photocolorimetrically by the Bray No 1 method (Bray and Kurtz, 1945), K and Na were determined by the flame photometric method (Black, 1965). Ca and Mg were determined by the ethylene diaminetetra-acetic acid (EDTA) method (Allison, 1973).

Chlorine was determined titrimetrically (Dewis and Freita, 1970). Ten (10) ml water sample was pipetted into a $150 \mathrm{ml}$ conical flask. Three drops of potassium chromate were added into the flask as an indicator. The water sample was titrated with $0.02 \mathrm{~N} \mathrm{AgNO}_{3}$ to a reddish brown end point. Iron ( $\left.\mathrm{Fe}\right)$ was analyzed using the atomic absorption spectrophotometer (AAS) with UNICAM 929 spectrophotometer equipment according to the procedures of Allison (1973). The hydrogen ion concentration $(\mathrm{pH})$ was measured electronically on a direct reading $\mathrm{pH}$ meter using a glass of electrode with a saturated potassium chloride-calomel reference electrode (Dewis and Freita, 1970). The $\mathrm{pH}$ meter was calibrated with standard $\mathrm{pH}$ buffer solution of $\mathrm{pH} 4.0, \mathrm{pH} 7.0$ and $\mathrm{pH}$ 9.0; $50 \mathrm{ml}$ water sample was pipetted into a $100 \mathrm{ml}$ clean beaker and the electrode was dipped into the beaker. Lead and cadmium were determined in water sample using the method of AOAC (1990) and APHA (1995). Ten (10) ml of water samples of Pb were individually placed in a $500 \mathrm{ml}$ beaker. Each sample of $\mathrm{Pb}$ and $\mathrm{Cd}$ was heated in a water bath at $100^{\circ} \mathrm{C}$ to concentrate the sample to $40 \mathrm{ml} .5 \mathrm{ml}, 1.0 \mathrm{ml} \mathrm{HCl}$ solution was then added to the concentrated water and brought to $50 \mathrm{ml}$ volumetric flask. The levels of $\mathrm{Pb}$ and $\mathrm{Cd}$ were determined using the atomic absorption spectrophotometer (AOAC, 1990; APHA, 1995). Organic carbon by the wet oxidation method (Black, 1965), while Organic matter was obtained as Organic carbon $\times 1.72$ (Broadbent, 1965). 


\subsubsection{Statistical Analysis}

The data obtained from mineral nutrient contents of $D$. crassiflora leaf litter was analyzed using analysis of variance (ANOVA) and Fisher's Least Significant Difference (F-LSD) at $P \leq 0.05$ to determine significant difference between treatment means according to the procedures of Steel and Torrie (1980) and Alika (2006).

\section{Results}

\subsection{Nutrient Contents of the Leaf Litter of Diospyros crassiflora Species in 2016 and 2017}

3.1.1. Nitrogen $(\mathrm{N})$, Phosphorus $(\mathrm{P})$ and Potassium $(\mathrm{K})\left(\mathrm{mg} \cdot \mathrm{l}^{-1}\right)$ Contents

Table 1 shows the $\mathrm{N}$ contents of the leaf litter of $D$. crassiflora over time (Months; January-December, and Years of study: 2016 and 2017). No significant differences existed between the $\mathrm{N}$ contents of the leaf litters in the two study years, 2016 and 2017. In terms of Months, Table 1 shows that January and February (each with $\left.1.49 \mathrm{mg} \cdot \mathrm{l}^{-1}\right)$ had similar $(p \leq 0.05) \mathrm{N}$ contents which were significantly higher than the $\mathrm{N}$ contents of March (1.127 mg. $\left.\mathrm{l}^{-1}\right)$, April (1.31 $\left.\mathrm{mg} \cdot \mathrm{l}^{-1}\right)$, May $\left(1.37 \mathrm{mg} \cdot \mathrm{l}^{-1}\right)$, September $\left(1.39 \mathrm{mg} \cdot \mathrm{l}^{-1}\right)$, August $\left(1.40 \mathrm{mg} \cdot \mathrm{l}^{-1}\right)$, June $\left(1.42 \mathrm{mg} \cdot \mathrm{l}^{-1}\right)$, July $\left(1.43 \mathrm{mg} \cdot \mathrm{l}^{-1}\right)$, and November $\left(1.45 \mathrm{mg} \cdot \mathrm{l}^{-1}\right)$. However, January and February $\mathrm{N}$ contents (each $1.49 \mathrm{mg} \cdot \mathrm{l}^{-1}$ ) were statistically similar to those of October and December (each $1.47 \mathrm{mg} \cdot \mathrm{l}^{-1}$ ). The statistically similar $\mathrm{N}$ contents of March $\left(1.27 \mathrm{mg} \cdot \mathrm{l}^{-1}\right)$ and April $\left(1.31 \mathrm{mg} \cdot \mathrm{l}^{-1}\right)$ had significantly the least $\mathrm{N}$ values. In terms of Years $\times$ Months treatment interactions, the statistically similar $\mathrm{N}$ contents of January, 2016 and February, $2017\left(1.51 \mathrm{mg} \cdot \mathrm{l}^{-1} \mathrm{each}\right)$ had significantly the highest $\mathrm{N}$ contents. The statistically similar N contents of March, 2017 (1.25 $\left.\mathrm{mg} \cdot \mathrm{l}^{-1}\right)$ and March, $2016\left(1.28 \mathrm{mg} \cdot \mathrm{l}^{-1}\right)$ gave the least $(p \leq 0.05)$ results.

Table 1 summarizes the results of the $\mathrm{P}$ contents of leaf litter of $D$. crassiflora over time (Months: January-December), and Years (2016 and 2017). The table shows that there were no significant differences between the P contents of the two Years of study (2016 and 2017), Months of study (January-December) and even the treatment interaction of Years $\times$ Months.

Table 1 shows the Potassium (K) contents of the leaf litters of $D$. crassiflora overtime (Months: January-December) and Years (2016 and 2017). In terms of Years, no significant differences existed between the K contents of 2016 and 2017. The table shows that the statistically similar $\mathrm{K}$ contents of March $(0.73$ $\left.\mathrm{mg} \cdot \mathrm{l}^{-1}\right)$, April $\left(0.71 \mathrm{mg} \cdot \mathrm{l}^{-1}\right)$, June $\left(0.72 \mathrm{mg} \cdot \mathrm{l}^{-1}\right)$, November $\left(0.72 \mathrm{mg} \cdot \mathrm{l}^{-1}\right)$ and December $\left(0.71 \mathrm{mg} \cdot \mathrm{l}^{-1}\right)$ were significantly higher than those of January $(0.15$ $\left.\mathrm{mg} \cdot \mathrm{l}^{-1}\right)$, February $\left(0.62 \mathrm{mg} \cdot \mathrm{l}^{-1}\right)$, May $\left(0.62 \mathrm{mg} \cdot \mathrm{l}^{-1}\right)$, July $\left(0.44 \mathrm{mg} \cdot \mathrm{l}^{-1}\right)$, August $\left(0.68 \mathrm{mg} \cdot \mathrm{l}^{-1}\right)$, September $\left(0.61 \mathrm{mg} \cdot \mathrm{l}^{-1}\right)$ and October $\left(0.67 \mathrm{mg} \cdot \mathrm{l}^{-1}\right)$. The statistically similar K contents of February $\left(0.62 \mathrm{mg} \cdot \mathrm{l}^{-1}\right)$ and September $\left(0.61 \mathrm{mg} \cdot \mathrm{l}^{-1}\right)$ gave the least $(p \leq 0.05)$ results. In terms of the $\mathrm{K}$ contents of the Years $\times$ Months treatment interactions, May, 2016, June, 2016 and December, 2017 had significantly higher $\mathrm{K}$ contents (each with $0.73 \mathrm{mg} \cdot \mathrm{l}^{-1}$ ) than February, 2016 and September, 2017 (each with $\left.0.61 \mathrm{mg} \cdot \mathrm{l}^{-1}\right)$, September, $2017\left(0.62 \mathrm{mg} \cdot \mathrm{l}^{-1}\right)$, October, 
Table 1. Nitrogen (N), Phosphorus (P) and Potassium (K) $\left(\mathrm{mg} \cdot \mathrm{l}^{-1}\right)$ of the leaf litter of Diospyros crassiflora in a plantation at Umuahia, Nigeria.

\begin{tabular}{|c|c|c|c|c|c|c|c|c|c|}
\hline \multirow[b]{3}{*}{ Months } & \multicolumn{3}{|c|}{ Nitrogen $(\mathrm{N})\left(\mathrm{mg} \cdot \mathrm{l}^{-1}\right)$ contents } & \multicolumn{3}{|c|}{ Phosphorus $(\mathrm{P})\left(\mathrm{mg} \cdot \mathrm{l}^{-1}\right)$ contents } & \multicolumn{3}{|c|}{ Potassium $(\mathrm{K})\left(\mathrm{mg} \cdot \mathrm{l}^{-1}\right)$ contents } \\
\hline & \multicolumn{2}{|c|}{ Years of Study } & \multirow{2}{*}{$\begin{array}{c}\text { Mean } \\
\text { (Months) }\end{array}$} & \multicolumn{2}{|c|}{ Years of Study } & \multirow{2}{*}{$\begin{array}{c}\text { Mean } \\
\text { (Months) }\end{array}$} & \multicolumn{2}{|c|}{ Years of Study } & \multirow{2}{*}{$\begin{array}{c}\text { Mean } \\
\text { (Months) }\end{array}$} \\
\hline & 2016 & 2017 & & 2016 & 2017 & & 2016 & 2017 & \\
\hline January & 1.51 & 1.46 & 1.49 & 0.19 & 0.17 & 0.18 & 0.64 & 0.66 & 0.65 \\
\hline February & 1.47 & 1.51 & 1.49 & 0.16 & 0.17 & 0.17 & 0.61 & 0.64 & 0.62 \\
\hline March & 1.28 & 1.25 & 1.27 & 0.20 & 0.10 & 0.19 & 0.72 & 0.71 & 0.73 \\
\hline April & 1.31 & 1.30 & 1.31 & 0.18 & 0.16 & 0.17 & 0.72 & 0.71 & 0.71 \\
\hline May & 1.40 & 1.34 & 1.37 & 0.17 & 0.17 & 0.17 & 0.73 & 0.65 & 0.69 \\
\hline June & 1.40 & 1.43 & 1.42 & 0.17 & 0.18 & 0.18 & 0.73 & 0.71 & 0.72 \\
\hline July & 1.41 & 1.44 & 1.43 & 0.18 & 0.18 & 0.18 & 0.64 & 0.64 & 0.64 \\
\hline August & 1.39 & 1.41 & 1.40 & 0.18 & 0.19 & 0.19 & 0.70 & 0.65 & 0.68 \\
\hline September & 1.38 & 1.41 & 1.39 & 0.18 & 0.20 & 0.19 & 0.62 & 0.61 & 0.61 \\
\hline October & 1.47 & 1.46 & 1.47 & 0.18 & 0.18 & 0.18 & 0.63 & 0.70 & 0.67 \\
\hline November & 1.44 & 1.46 & 1.45 & 0.18 & 0.18 & 0.18 & 0.73 & 0.72 & 0.72 \\
\hline December & 1.47 & 1.46 & 1.47 & 0.21 & 0.16 & 0.18 & 0.68 & 0.73 & 0.71 \\
\hline \multirow[t]{2}{*}{ Mean (Years) } & 1.41 & 1.41 & 0.18 & 0.18 & 0.68 & 0.68 & & & \\
\hline & \multicolumn{4}{|c|}{ F-LSD (0.05) for $\mathrm{N}\left(\mathrm{mg} \cdot \mathrm{l}^{-1}\right)$} & \multicolumn{2}{|c|}{ F-LSD (0.05) for P $\left(\mathrm{mg} \cdot \mathrm{l}^{-1}\right)$} & \multicolumn{3}{|c|}{ F-LSD (0.05) for K $\left(\mathrm{mg} \cdot \mathrm{l}^{-1}\right)$} \\
\hline \multicolumn{2}{|l|}{ Year $(Y)$} & \multicolumn{3}{|c|}{ NS } & \multicolumn{2}{|c|}{ NS } & \multicolumn{3}{|c|}{ NS } \\
\hline \multicolumn{2}{|c|}{ Months (M) } & \multicolumn{3}{|c|}{0.03} & \multicolumn{2}{|c|}{ NS } & \multicolumn{3}{|c|}{0.03} \\
\hline \multicolumn{2}{|c|}{ Year $\times$ Months $(\mathrm{Y} \times \mathrm{M})$} & \multicolumn{2}{|r|}{0.04} & & \multicolumn{2}{|c|}{ NS } & \multicolumn{3}{|c|}{0.04} \\
\hline
\end{tabular}

F-LSD = Fisher least significant different, NS = Not significant.

$2016\left(0.63 \mathrm{mg} \cdot \mathrm{l}^{-1}\right)$, January, 2016, February, 2016, July, 2016 and July, 2017 (each with $\left.0.64 \mathrm{mg} \cdot \mathrm{l}^{-1}\right)$, May, 2017 and August, 2017 (0.68 mg.1 $\mathrm{l}^{-1}$ each), January, 2017 $\left(0.66 \mathrm{mg} \cdot \mathrm{l}^{-1}\right)$ and December, $2016\left(0.68 \mathrm{mg} \cdot \mathrm{l}^{-1}\right)$. However, the $\mathrm{K}$ contents of May, 2016, June, 2016 and December, $2017\left(0.73 \mathrm{mg}^{-1} \mathrm{l}^{-1}\right)$ were not significantly different from those of October, 2017 and August, 2016 (0.70 mg. $\mathrm{l}^{-1}$ each), March, 2017, April, 2017 and June, 2017 (0.71 mg. $\left.\mathrm{l}^{-1}\right)$, and March, 2016, November,

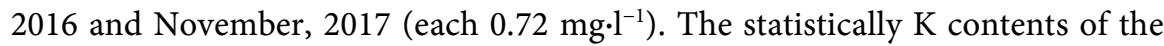
Years $\times$ Months Interactions of February, 2016 and September, 2017 each 0.61 $\left.\mathrm{mg} \cdot \mathrm{l}^{-1}\right)$, September, $2016\left(0.62 \mathrm{mg} \cdot \mathrm{l}^{-1}\right)$, October, $2016\left(0.63 \mathrm{mg} \cdot \mathrm{l}^{-1}\right)$, January, 2016, February, July, 2016 and July, 2017 (each $0.64 \mathrm{mg} \cdot \mathrm{l}^{-1}$ ) had significantly the least results.

\subsubsection{Sodium (Na), Calcium (Ca) and Magnium (Mg) (mg-1-1) Contents}

Table 2 shows the $\mathrm{Na}$ contents of the leaf litter of $D$. crassiflora over time Months (January-December) and years (2016 and 2017). In terms of years, 2016 had significantly higher $\mathrm{Na}$ contents than 2017. In terms of months, July $(0.40$ $\left.\mathrm{mg} \cdot \mathrm{l}^{-1}\right)$ and September $\left(0.25 \mathrm{mg} \cdot \mathrm{l}^{-1}\right)$ had significantly the highest and least $\mathrm{Na}$ 
Table 2. Sodium (Na), Calcium (Ca) and Magnesium $(\mathrm{Mg})\left(\mathrm{mg} \cdot \mathrm{l}^{-1}\right)$ contents of the leaf litter of Diospyros crassiflora in a plantation at Umuahia, Nigeria.

\begin{tabular}{|c|c|c|c|c|c|c|c|c|c|}
\hline \multirow[b]{3}{*}{ Months } & \multicolumn{3}{|c|}{ Sodium $(\mathrm{Na})\left(\mathrm{mg} \cdot \mathrm{l}^{-1}\right)$ contents } & \multicolumn{3}{|c|}{ Calcium $(\mathrm{Ca})\left(\mathrm{mg} \cdot \mathrm{l}^{-1}\right)$ contents } & \multicolumn{3}{|c|}{ Magnesium $(\mathrm{Mg})\left(\mathrm{mg} \cdot 1^{-1}\right)$ contents } \\
\hline & \multicolumn{2}{|c|}{ Years of Study } & \multirow{2}{*}{$\begin{array}{c}\text { Mean } \\
\text { (Months) }\end{array}$} & \multicolumn{2}{|c|}{ Years of Study } & \multirow{2}{*}{$\begin{array}{c}\text { Mean } \\
\text { (Months) }\end{array}$} & \multicolumn{2}{|c|}{ Years of Study } & \multirow{2}{*}{$\begin{array}{c}\text { Mean } \\
\text { (Months) }\end{array}$} \\
\hline & 2016 & 2017 & & 2016 & 2017 & & 2016 & 2017 & \\
\hline January & 0.32 & 0.28 & 0.30 & 1.55 & 1.53 & 1.58 & 0.31 & 0.30 & 0.31 \\
\hline February & 0.33 & 0.31 & 0.32 & 1.55 & 1.61 & 1.58 & 0.32 & 0.33 & 0.33 \\
\hline March & 0.32 & 0.32 & 0.32 & 1.56 & 1.60 & 1.58 & 0.32 & 0.33 & 0.33 \\
\hline April & 0.34 & 0.35 & 0.34 & 1.59 & 1.61 & 1.60 & 0.33 & 0.33 & 0.33 \\
\hline May & 0.36 & 0.31 & 0.34 & 1.57 & 1.64 & 1.61 & 0.31 & 0.32 & 0.31 \\
\hline June & 0.38 & 0.28 & 0.33 & 1.60 & 1.60 & 1.61 & 0.31 & 0.33 & 0.32 \\
\hline July & 0.40 & 0.39 & 0.40 & 1.44 & 1.44 & 1.44 & 0.33 & 0.31 & 0.32 \\
\hline August & 0.35 & 0.25 & 029 & 1.46 & 1.45 & 1.46 & 0.32 & 0.30 & 0.31 \\
\hline September & 0.32 & 0.18 & 0.25 & 1.43 & 1.44 & 1.44 & 0.32 & 0.32 & 0.32 \\
\hline October & 0.37 & 0.32 & 0.34 & 1.61 & 1.69 & 1.65 & 0.28 & 0.28 & 028 \\
\hline November & 0.33 & 0.28 & 0.30 & 1.56 & 1.30 & 1.58 & 0.32 & 0.32 & 0.32 \\
\hline December & 0.32 & 0.31 & 0.32 & 1.56 & 1.56 & 1.57 & 0.29 & 0.30 & 0.29 \\
\hline Mean (Years) & 0.35 & 0.30 & 1.57 & 1.56 & 0.32 & 0.31 & & & \\
\hline
\end{tabular}

\begin{tabular}{cccc}
\hline & F-LSD $(0.05)$ for N $\left(\mathrm{mg} \cdot \mathrm{l}^{-1}\right)$ & F-LSD $(0.05)$ for P $\left(\mathrm{mg} \cdot \mathrm{l}^{-1}\right)$ & F-LSD $(0.05)$ for K $\left(\mathrm{mg} \cdot \mathrm{l}^{-1}\right)$ \\
\hline Year $(\mathrm{Y})$ & 0.01 & 0.001 & $\mathrm{NS}$ \\
Months $(\mathrm{M})$ & 0.02 & 0.02 & 0.02 \\
Year $\times$ Months $(\mathrm{Y} \times \mathrm{M})$ & 0.03 & 0.02 & $\mathrm{NS}$ \\
\hline
\end{tabular}

F-LSD = Fisher least significant different, NS = Not significant.

contents respectively. Summary of the $\mathrm{Na}$ contents of the months are significantly as follows: July $>$ April $=$ May $=$ October $=$ June; June $=$ February $=$ March $=$ December $>$ September, November and January. In terms of Interaction Years $\times$ Months, July, $2016\left(0.40 \mathrm{mg} \cdot \mathrm{l}^{-1}\right)$ had significantly higher $\mathrm{Na}$ contents than September, $2017\left(0.18 \mathrm{mg} \cdot \mathrm{l}^{-1}\right)$, August, $2017\left(0.24 \mathrm{mg} \cdot \mathrm{l}^{-1}\right)$, November, $2017\left(0.27 \mathrm{mg} \cdot \mathrm{l}^{-1}\right.$ ), January, 2017 and June, 2017 (each, $0.28 \mathrm{mg} \cdot \mathrm{l}^{-1}$ ), February, 2017, May, 2017 and December, 2017 (each $0.31 \mathrm{mg}^{-1}$ ), March, 2017, October, 2017, December, 2016, September, 2016, March, 2016 and January, 2016 (each $0.32 \mathrm{mg} \cdot \mathrm{l}^{-1}$ ), November, 2016 and February, 2016 (each $0.33 \mathrm{mg} \cdot \mathrm{l}^{-1}$ ), April, 2016 (0.34 mg. $\mathrm{l}^{-1}$ ), August, 2016 and April, 2017 (each $0.35 \mathrm{mg} \cdot \mathrm{l}^{-1}$ ), May, 2016 (0.36 $\left.\mathrm{mg} \cdot \mathrm{l}^{-1}\right)$ and October, $2016\left(0.37 \mathrm{mg} \cdot \mathrm{l}^{-1}\right)$. However, the Na contents of June, 2016, $\left(0.38 \mathrm{mg} \cdot \mathrm{l}^{-1}\right)$, July, $2017\left(0.39 \mathrm{mg} \cdot \mathrm{l}^{-1}\right)$ and July, $2016\left(0.40 \mathrm{mg} \cdot \mathrm{l}^{-1}\right)$ were statistically similar. The table shows that September, 2017 had significantly the least $\mathrm{Na}$ content $\left(0.18 \mathrm{mg} \cdot \mathrm{l}^{-1}\right)$.

Table 2 also shows the Ca contents of the leaf litter of Diospyros crassiflora overtime (months in the two study years 2016 and 2017) at Umuahia, Nigeria. In 
terms of Years (Y), 2017 (1.56 mg. $\left.\mathrm{l}^{-1}\right)$ had significantly higher Ca content than $2016\left(1.54 \mathrm{mg} \cdot \mathrm{l}^{-1}\right)$. In terms of months $(\mathrm{M})$, October $\left(1.65 \mathrm{mg} \cdot \mathrm{l}^{-1}\right)$ had the highest $(p \leq 0.05)$ Ca contents. July and September each with $\left.1.44 \mathrm{mg} \cdot \mathrm{l}^{-1}\right)$ had significantly the least $\mathrm{Ca}$ contents. Summary of the Ca contents of the specific months are significantly as follows: October $>$ May $=$ June $=$ April $>$ February $=$ March $=$ November $=$ December $>$ January $>$ August $>$ July $=$ September. In terms of Interaction Years $\times$ Months $(\mathrm{Y} \times \mathrm{M})$, October, $2017\left(1.69 \mathrm{mg} \cdot \mathrm{l}^{-1}\right)$ and September, $2016\left(1.43 \mathrm{mg} \cdot \mathrm{l}^{-1}\right)$ had significantly the highest and least Ca contents respectively.

Table 3 shows the Mg contents of the leaf litter of Diospyros crassiflora overtime (months in 2016 and 2017) at Umuahia, Nigeria. The table shows that no significant differences existed between the Magnesium contents of the study years, in 2016 and 2017. In terms of the months of study, February, March and April (each with $0.33 \mathrm{mg} \cdot \mathrm{l}^{-1} \mathrm{Mg}$ content) had significantly higher $\mathrm{Mg}$ contents than January, May and August (each with $\left.0.31 \mathrm{mg} \cdot \mathrm{l}^{-1}\right)$, October $\left(0.28 \mathrm{mg} \cdot \mathrm{l}^{-1}\right)$ and December $\left(0.29 \mathrm{mg} \cdot \mathrm{l}^{-1}\right)$. However, the $\mathrm{Mg}$ contents of February, March and April were statistically similar to those of June, July, September, November (each with $0.32 \mathrm{mg} \cdot \mathrm{l}^{-1}$ ). The $\mathrm{Mg}$ contents of June, July, September and November (each $0.32 \mathrm{mg} \cdot \mathrm{l}^{-1}$ ) were not also significantly different from each that of January, May and August (each with $0.31 \mathrm{mg} \cdot \mathrm{l}^{-1}$ ). The statistically similar $\mathrm{Mg}$ contents of October $\left(0.28 \mathrm{mg} \cdot \mathrm{l}^{-1}\right)$ and December $\left(0.29 \mathrm{mg} \cdot \mathrm{l}^{-1}\right)$ had significantly the least results. Table 2 also shows no significant differences existed between the Mg contents of Years $\times$ Months treatment interactions.

\subsubsection{Chlorine ( $\mathrm{Cl})\left(\mathrm{mg} \cdot \mathrm{l}^{-1}\right)$, Iron $(\mathrm{Fe})\left(\mathrm{mg}^{-1} \mathrm{l}^{-1}\right)$ and $\mathrm{pH}$ Values Contents}

Table 3 shows the chlorine $(\mathrm{Cl})$ contents of the leaf litter of Diospyros crassiflora species in 2016 and 2017. No significant differences existed between the $\mathrm{Cl}$ contents of the two years of study, 2016 and 2017. The $\mathrm{Cl}$ contents of the Years $\times$ Months treatment interactions were not significantly different from each other. The $\mathrm{Cl}$ contents of the months of study were significantly different. The statistically similar $\mathrm{Cl}$ contents of May $\left(0.27 \mathrm{mg} \cdot \mathrm{l}^{-1}\right)$, June $\left(0.27 \mathrm{mg} \cdot \mathrm{l}^{-1}\right)$, July $(0.28$ $\left.\mathrm{mg} \cdot \mathrm{l}^{-1}\right)$, August $\left(0.27 \mathrm{mg} \cdot \mathrm{l}^{-1}\right)$ and September $\left(0.27 \mathrm{mg} \cdot \mathrm{l}^{-1}\right)$ had significantly the highest $\mathrm{Cl}$ values. October $\left(0.20 \mathrm{mg} \cdot \mathrm{l}^{-1}\right)$ had the least $(P \leq 0.05) \mathrm{Cl}$ contents. Summary of the $\mathrm{Cl}$ contents of the months of study were significantly as follows: May $=$ June $=$ July $=$ August $=$ September $>$ April $=$ March March $>$ January $=$ December $>$ October.

Table 3 shows the Iron (Fe) contents of the leaf litter of Diospyros crassiflora overtime (Months: January-December) and Years: 2016 and 2017. Fe contents of leaves of $D$. crassiflora within the study months, February and April each with similar Fe contents $\left(1.09 \mathrm{mg} \cdot \mathrm{l}^{-1}\right)$ had significantly higher Fe contents than March, June, July, August and September. However, the Fe contents of February and April were statistically similar to those of January, May, October, November and December. The Fe contents of March, May, June, July, August, September and October were also statistically were similar. 
Table 3. Chlorine (Cl), Iron (Fe) and Magnesium $(\mathrm{Mg})\left(\mathrm{mg} \cdot \mathrm{l}^{-1}\right)$ contents of the leaf litter of Diospyros crassiflora in a plantation at Umuahia, Nigeria.

\begin{tabular}{|c|c|c|c|c|c|c|c|c|c|}
\hline \multirow[b]{3}{*}{ Months } & \multicolumn{3}{|c|}{ Chlorine $(\mathrm{Cl})\left(\mathrm{mg} \cdot \mathrm{l}^{-1}\right)$ contents } & \multicolumn{3}{|c|}{ Iron $(\mathrm{Fe})\left(\mathrm{mg} \cdot \mathrm{l}^{-1}\right)$ contents } & \multicolumn{3}{|c|}{$\mathrm{pH}$-value contents } \\
\hline & \multicolumn{2}{|c|}{ Years of Study } & \multirow{2}{*}{$\begin{array}{c}\text { Mean } \\
\text { (Months) }\end{array}$} & \multicolumn{2}{|c|}{ Years of Study } & \multirow{2}{*}{$\begin{array}{c}\text { Mean } \\
\text { (Months) }\end{array}$} & \multicolumn{2}{|c|}{ Years of Study } & \multirow{2}{*}{$\begin{array}{c}\text { Mean } \\
\text { (Months) }\end{array}$} \\
\hline & 2016 & 2017 & & 2016 & 2017 & & 2016 & 2017 & \\
\hline January & 0.22 & 0.22 & 0.22 & 1.07 & 6.08 & 1.07 & 1.25 & 1.27 & 1.26 \\
\hline February & 0.23 & 0.22 & 0.23 & 1.09 & 1.09 & 1.09 & 1.35 & 1.35 & 1.35 \\
\hline March & 0.23 & 0.24 & 0.24 & 0.74 & 0.74 & 0.74 & 1.24 & 1.30 & 113 \\
\hline April & 0.24 & 0.25 & 0.25 & 1.09 & 1.09 & 1.09 & 1.02 & 1.08 & 1.05 \\
\hline May & 0.27 & 0.27 & 0.27 & 0.87 & 0.88 & 0.88 & 1.13 & 1.26 & 1.20 \\
\hline June & 0.28 & 0.27 & 0.27 & 0.09 & 0.78 & 0.84 & 1.22 & 1.23 & 1.23 \\
\hline July & 0.28 & 0.28 & 0.28 & 0.83 & 0.83 & 0.83 & 1.29 & 1.31 & 1.30 \\
\hline August & 0.27 & 0.27 & 0.27 & 0.84 & 0.89 & 0.86 & 1.22 & 1.08 & 1.15 \\
\hline September & 0.28 & 0.25 & 0.27 & 0.81 & 0.85 & 0.83 & 1.12 & 1.08 & 1.10 \\
\hline October & 0.19 & 0.21 & 0.20 & 0.98 & 0.95 & 0396 & 1.10 & 1.16 & 1.12 \\
\hline November & 0.25 & 0.22 & 0.23 & 0.97 & 1.08 & 1.03 & 1.16 & 1.19 & 1.17 \\
\hline December & 0.22 & 0.22 & 0.22 & 1.04 & 1.06 & 1.05 & 1.14 & 1.13 & 1.14 \\
\hline \multirow[t]{2}{*}{ Mean (Years) } & 0.25 & 0.24 & 0.94 & 0.94 & 1.19 & 1.18 & & & \\
\hline & \multicolumn{4}{|c|}{ F-LSD (0.05) for $\mathrm{Cl}\left(\mathrm{mg} \cdot \mathrm{l}^{-1}\right)$} & \multicolumn{2}{|c|}{ F-LSD (0.05) for Fe $\left(\mathrm{mg} \cdot \mathrm{l}^{-1}\right)$} & \multicolumn{3}{|c|}{ F-LSD (0.05) for $\mathrm{pH}$-value contents } \\
\hline \multicolumn{2}{|l|}{ Year (Y) } & \multicolumn{2}{|r|}{ NS } & \multicolumn{3}{|c|}{ NS } & \multicolumn{3}{|c|}{ NS } \\
\hline \multicolumn{2}{|c|}{ Months (M) } & \multicolumn{2}{|r|}{0.02} & \multicolumn{3}{|c|}{0.23} & \multicolumn{3}{|c|}{0.08} \\
\hline \multicolumn{2}{|c|}{ Year $\times$ Months $(\mathrm{Y} \times \mathrm{M})$} & \multicolumn{2}{|r|}{ NS } & \multicolumn{3}{|c|}{ NS } & \multicolumn{3}{|c|}{0.10} \\
\hline
\end{tabular}

F-LSD = Fisher least significant different, NS = Not significant.

Table 3 also shows the pH-values of the leaf litter of Diospyros crassiflora had no significant differences existed between years of study (2016 and 2017). In terms of months, the table shows that February (1.35) had significantly higher pH-value than January (1.26), March (1.13), April (1.05), May (1.20), June (1.23), August (1.15), September (1.10), October (1.12), November (1.17) and December (1.14). However, no significant difference existed between the $\mathrm{pH}$-values February (1.36) and July (1.30). Although the $\mathrm{pH}$-values of April, September and October were statistically similar, April (1.05) had significantly lower $\mathrm{pH}$-value than January (1.26), February (1.35), March (1.13), June (1.23), July (1.30), August (1.15), November (1.17) and December (1.14). In terms of Interactions Years $\times$ Months the table shows that although February in 2016 (1.35) and 2017 (1.35) had statistically the same pH-values with January, 2017 (1.27), March, 2016 (1.24), May, 2017 (1.26) and July in 2016 (1.29) and 2017 (1.31), the $\mathrm{pH}$ values of February in 2016 and 2017 were significantly higher than those of the other months in 2016 and 2017. Table 3 also shows that except the months of April, 2017, August, 2017 (1.05), September in 2016 (1.12) and 2017 (1.08) and 
October, 2016 (1.10), April, 2016 (1.08) had significantly the least pH-values.

\subsubsection{Organic Carbon (Org. C) (mg. $\left.\mathrm{l}^{-1}\right)$, Organic Matter (Org. M) (mg. $\left.\mathrm{l}^{-1}\right)$, Cadmium (Cd) (mg:l-1) and Lead (Pb) $\left(\mathrm{mg}^{-1} \mathrm{l}^{-1}\right)$ Contents}

Table 4 shows the Org. C contents of D. crassiflora over study Months; January-December, and study Years: 2016 and 2017. In terms of Years, 2016 had higher $(p \leq 0.05)$ Org. $\mathrm{C}$ content than 2017. In terms of Months, August $(0.38$ $\left.\mathrm{mg} \cdot \mathrm{l}^{-1}\right)$ and May $\left(0.14 \mathrm{mg} \cdot \mathrm{l}^{-1}\right)$ had significantly the highest and least Org. $\mathrm{C}$ contents respectively. Summary of the Org. $\mathrm{C}$ contents of the months of study are significantly as follows: August $>$ September $>$ July $=$ February $>$ December $=$ January $=$ November $>$ May, October, March, June, April $=$ June $>$ May, October and March, October $=$ March $>$ May. Years $\times$ Months interaction were statistically similar Org. C contents of August, $2016\left(0.39 \mathrm{mg} \cdot \mathrm{l}^{-1}\right)$, August, 2017 and September, 2016 (each $0.37 \mathrm{mg} \cdot \mathrm{l}^{-1}$ ) had significantly the highest results. November, $2016\left(0.15 \mathrm{mg} \cdot \mathrm{l}^{-1}\right)$ and May, $2017\left(0.15 \mathrm{mg} \cdot \mathrm{l}^{-1}\right)$ with statistically similar results, had significantly the least Org C. values.

Table 4 shows the Org. M contents of the leaf litter of D. crassiflora over time

Table 4. Org. C, Org. $\mathrm{M}, \mathrm{Cd}$ and $\mathrm{Pb}\left(\mathrm{mg} \cdot \mathrm{l}^{-1}\right)$ contents of the leaf litter of Diospyros crassiflora in a plantation at Umuahia, Nigeria.

\begin{tabular}{|c|c|c|c|c|c|c|c|c|c|c|c|c|}
\hline & \multicolumn{3}{|c|}{ Org. $\mathrm{C}\left(\mathrm{mg} \cdot \mathrm{l}^{-1}\right)$ contents } & \multicolumn{3}{|c|}{ Org. $\mathrm{M}\left(\mathrm{mg} \cdot \mathrm{l}^{-1}\right)$ contents } & \multicolumn{3}{|c|}{$\mathrm{Cd}\left(\mathrm{mg} \cdot \mathrm{l}^{-1}\right)$ contents } & \multicolumn{3}{|c|}{$\mathrm{Pb}\left(\mathrm{mg} \cdot \mathrm{l}^{-1}\right)$ contents } \\
\hline & \multicolumn{2}{|c|}{ Years of Study } & \multirow{2}{*}{$\begin{array}{c}\text { Mean } \\
\text { (Months) }\end{array}$} & \multicolumn{2}{|c|}{ Years of Study } & \multirow{2}{*}{$\begin{array}{c}\text { Mean } \\
\text { (Months) }\end{array}$} & \multicolumn{2}{|c|}{ Years of Study } & \multirow{2}{*}{$\begin{array}{c}\text { Mean } \\
\text { (Months) }\end{array}$} & \multicolumn{2}{|c|}{ Years of Study } & \multirow{2}{*}{$\begin{array}{c}\text { Mean } \\
\text { (Months }\end{array}$} \\
\hline & 2016 & 2017 & & 2016 & 2017 & & 2016 & 2017 & & 2016 & 2017 & \\
\hline January & 0.29 & 0.24 & 0.27 & 0.42 & 0.41 & 0.41 & 0.02 & 0.01 & 0.01 & 0.125 & 1.26 & 1.26 \\
\hline February & 0.32 & 0.27 & 0.30 & 0.47 & 0.51 & 0.49 & 0.01 & 0.07 & 0.04 & 1.38 & 1.32 & 1.35 \\
\hline March & 0.17 & 0.16 & 0.17 & 0.27 & 0.29 & 0.28 & 0.07 & 0.07 & 0.07 & 1.03 & 1.00 & 1.02 \\
\hline April & 0.26 & 0.5 & 0.25 & 0.33 & 0.25 & 0.29 & 0.10 & 0.04 & 0.07 & 1.08 & 1.06 & 1.07 \\
\hline May & 0.15 & 0.13 & 0.14 & 0.25 & 0.25 & 0.25 & 0.01 & 0.01 & 0.01 & 1.26 & 1.23 & 1.25 \\
\hline June & 0.25 & 0.22 & 0.24 & 0.36 & 0.32 & 0.34 & 0.02 & 0.02 & 0.02 & 1.20 & 1.21 & 1.24 \\
\hline July & 0.32 & 0.28 & 030 & 0.56 & 0.40 & 0.46 & 0.01 & 0.01 & 0.01 & 1.31 & 1.39 & 1.31 \\
\hline August & 0.39 & 0.37 & 0.38 & 0.61 & 0.53 & 0.57 & 0.01 & 0.01 & 0.01 & 1.31 & 1.39 & 1.31 \\
\hline September & 0.37 & 0.27 & 0.32 & 0.56 & 0.55 & 0.55 & 0.01 & 0.01 & 0.01 & 1.08 & 1.05 & 1.07 \\
\hline October & 0.18 & 0.16 & 0.17 & 0.27 & 0.25 & 0.26 & 0.01 & 0.01 & 0.01 & 1.17 & 1.13 & 1.15 \\
\hline November & 0.31 & 0.22 & 0.27 & 031 & 0.27 & 0.29 & 0.02 & 0.02 & 0.02 & 1.19 & 1.16 & 1.17 \\
\hline December & 0.31 & 0.26 & 0.28 & 0.30 & 0.31 & 0.31 & 0.02 & 0.04 & 0.03 & 1.09 & 1.22 & 1.16 \\
\hline \multirow[t]{2}{*}{ Mean (Years) } & 0.28 & 0.28 & 0.39 & 0.36 & 0.03 & 0.03 & 1.17 & 1.18 & & & & \\
\hline & & \multicolumn{3}{|c|}{$\begin{array}{l}\text { F-LSD (0.05) for } \\
\text { Org. C }\left(\mathrm{mg} \cdot l^{-1}\right)\end{array}$} & \multicolumn{2}{|c|}{$\begin{array}{l}\text { F-LSD (0.05) for } \\
\text { Org. M }\left(\mathrm{mg} \cdot \mathrm{l}^{-1}\right)\end{array}$} & & \multicolumn{2}{|c|}{$\begin{array}{l}\text { F-LSD (0.05) for } \\
\text { Cd }\left(\mathrm{mg} \cdot \mathrm{l}^{-1}\right)\end{array}$} & \multicolumn{3}{|c|}{$\begin{array}{l}\text { F-LSD (0.05) for } \\
\text { Pb }\left(\mathrm{mg} \cdot \mathrm{l}^{-1}\right)\end{array}$} \\
\hline \multicolumn{2}{|l|}{ Year $(\mathrm{Y})$} & \multicolumn{3}{|c|}{0.02} & \multicolumn{2}{|r|}{ NS } & & \multicolumn{2}{|c|}{ NS } & \multicolumn{3}{|c|}{ NS } \\
\hline \multicolumn{2}{|c|}{ Months (M) } & \multicolumn{3}{|c|}{0.02} & \multicolumn{2}{|r|}{0.23} & & \multicolumn{2}{|c|}{0.03} & \multicolumn{3}{|c|}{0.01} \\
\hline \multicolumn{3}{|c|}{ Year $\times$ Months $(\mathrm{Y} \times \mathrm{M})$} & \multicolumn{2}{|l|}{0.03} & \multicolumn{2}{|r|}{ NS } & & \multicolumn{2}{|c|}{ NS } & \multicolumn{3}{|c|}{0.02} \\
\hline
\end{tabular}

F-LSD $=$ Fisher least significant different, NS = Not significant. 
(Months; January-December, and Years: 2016 and 2017). The Years, 2016 had significantly higher Org. M contents than 2017. In terms of Months, August $\left(0.57 \mathrm{mg} \cdot \mathrm{l}^{-1}\right)$ and September $\left(0.55 \mathrm{mg} \cdot \mathrm{l}^{-1}\right)$ with statistically similar Org. M contents had significantly the highest Org. M values. May, followed by October had significantly the least Org. M contents. Summary of the Org. M contents of the months are significantly as follows: August $=$ September $>$ February $>$ July $>$ January $>$ June $>$ December $=$ April $=$ November $=$ March $>$ May. March $=$ October, October = May. The table also shows that April and November $(0.29$ $\left.\mathrm{mg} \cdot \mathrm{l}^{-1}\right)$ had similar $(p \leq 0.05)$ Org. $\mathrm{M}$ values that were also significantly higher than those of January, May, October and March. The non-significantly different Org. $M$ values of March, April and November were higher than that of May. The treatment interactions of Years $\times$ Months, August in 2016 (0.61 $\left.\mathrm{mg} \cdot \mathrm{l}^{-1}\right)$ had significantly the highest Org. M content. The least $(p \leq 0.05)$ Org. $M$ results were obtained in the similar $(p \leq 0.05)$ values of April, 2017, May, 2016, October, 2016 and November, 2017 (each $0.27 \mathrm{mg} \cdot \mathrm{l}^{-1}$ ), and March, 2017 $\left(0.29 \mathrm{mg} \cdot \mathrm{l}^{-1}\right)$.

Table 4 shows the Cd contents of the leaf litter of Diospyros crassiflora overtime (Months: January-December) and Years: (2016 and 2017). The table shows that March had significantly the highest Cd content $\left(0.07 \mathrm{mg} \cdot \mathrm{l}^{-1}\right)$. February $(0.04$ $\left.\mathrm{mg} \cdot \mathrm{l}^{-1}\right)$ had higher $(P \leq 0.05) \mathrm{Cd}$ content than January, May, June, August and September each of which had $\left(0.01 \mathrm{mg} \cdot \mathrm{l}^{-1}\right)$. However, the Cd contents of February were statistically similar to those of July, October, November and December. The Cd contents of the following months: January, May, June, August and September (each $0.01 \mathrm{mg} \cdot \mathrm{l}^{-1}$ ), July, October and November (each $\left.0.02 \mathrm{mg} \cdot \mathrm{l}^{-1}\right)$ and December $\left(0.03 \mathrm{mg} \cdot \mathrm{l}^{-1}\right)$ were not significantly different from each other. Table 4 shows that no significant differences existed between study years (2016 and 2017) and between the treatments interactions of Year $\times$ Months.

Table 4 shows the $\mathrm{Pb}$ contents of the leaf litter of Diospyros crassiflora overtime (Months: January-December) and Years (2016 and 2017). In terms of the years of study (2016 and 2017), the Pb contents of the 2016 and 2017 were not significantly different from each other. In terms of the specific months of study, February $\left(1.36 \mathrm{mg} \cdot \mathrm{l}^{-1}\right)$ and March $\left(1.36 \mathrm{mg} \cdot \mathrm{l}^{-1}\right)$ had significantly the highest and least $\mathrm{Pb}$ contents respectively. Summary of the $\mathrm{Pb}$ contents of the study months are significantly as follows: February $>$ July $>$ January $>$ May $>$ June $>$ November $>$ December $>$ October $>$ August $>$ September $=$ April $>$ March. In terms of the $\mathrm{Pb}$ contents of the Years $\times$ Months treatment interactions, Table 4 shows that February in $2016\left(1.38 \mathrm{mg} \cdot \mathrm{l}^{-1}\right)$ and March $2017\left(1.00 \mathrm{mg} \cdot \mathrm{l}^{-1}\right)$ had significantly the highest and least $\mathrm{Pb}$ contents respectively. February in 2017 (1.32 $\left.\mathrm{mg} \cdot \mathrm{l}^{-1}\right)$ and July in $2016\left(1.32 \mathrm{mg} \cdot \mathrm{l}^{-1}\right)$ and $2017\left(1.39 \mathrm{mg} \cdot \mathrm{l}^{-1}\right)$ had higher mean monthly $\mathrm{Pb}$ contents than all the other months except February in 2016 (1.38 $\left.\mathrm{mg} \cdot \mathrm{l}^{-1}\right)$. March in $2016\left(1.03 \mathrm{mg} \cdot \mathrm{l}^{-1}\right)$ and $2017\left(1.00 \mathrm{mg} \cdot \mathrm{l}^{-1}\right)$ and August in 2016 $\left(1.04 \mathrm{mg} \cdot \mathrm{l}^{-1}\right)$ had comparatively the least $\mathrm{Pb}$ contents. 


\section{Discussion}

This study revealed that both macro and micro elements like: nitrogen $(\mathrm{N})$, phosphorus $(\mathrm{P})$ and potassium $(\mathrm{K})$, sodium $(\mathrm{Na})$, calcium $(\mathrm{Ca})$, magnesium $(\mathrm{Mg})$, chlorine $(\mathrm{Cl})$, iron $(\mathrm{Fe})$, lead $(\mathrm{Pb})$, organic carbon (Org. $\mathrm{C})$ and organic matter (Org. M.) contents etc. of $D$. crassiflora leaf litter over time (January-December) in 2016 and 2017 were significantly low within the period of study. Côté and Fyles (1994) also noted that White pine (Pinus strobus L.) was low in all nutrient contents, while red oak (Quercus rubra L.) leaf litter was not very acidic but was low in nutrient concentrations. The lower concentration of these nutrients in the leaf litter of $D$. crassiflora may be attributed to the species gene traits. However, Ekpendu (2003) reported high concentrations of Org. C, N, P, K, Na, Ca and Mg as well as high contents of carbon: nitrogen (C:N) ratio in the leaf of Irvingia wombulu leaf litter. Mangesh et al. (2019) work on Caesalpinea pulcherima leaf litter contents shows the highest level of available nitrogen and other mineral elements is not also in agreement with this finding. Schroth (2003) noted that, the nutrient concentrations in different parts of the biomass depend mainly on tree species, phenological stage, management and site factors. Low concentration of nutrients in the species could also be linked to the part (leaf litter) used in the study. Tree prunings normally have higher concentrations of mobile nutrients such as nitrogen, phosphorus, potassium and zinc than naturally fallen litter from which these elements are retranslocated by the tree prior to abscission (Marschner, 1995 and Schroth, 2003). The total input of N (1.41 and $1.41\left(\mathrm{mg} \cdot \mathrm{l}^{-1}\right)$ ), $\mathrm{P}\left(0.18\right.$ and $\left.0.18\left(\mathrm{mg} \cdot \mathrm{l}^{-1}\right)\right) \mathrm{K}\left(0.68\right.$ and $\left.0.68\left(\mathrm{mg} \cdot \mathrm{l}^{-1}\right)\right)$ contents were recorded in 2016 and 2017 respectively, through the above ground litter dependent on the nutrient concentration in the $D$. crassiflora leaf litter and its total production within the study period. The lower rates of total $\mathrm{N}$ and soil OM, lower $\mathrm{N}$ concentrations in green leaves and higher $\mathrm{N}$ resorption in poplar may indicate less stability in N nutrition (González et al., 2020). D. crassiflora as a member of family Ebenaceae is not nitrogen fixing tree, hence this could also contributes to low level of nitrogen and other mineral elements. Palm (1995) and Schroth (2003) noted that nitrogen fixing trees normally have higher nitrogen concentrations in the biomass than non-fixing species.

The quantity and nutrient concentrations of leaf litterfall vary significantly between tree species, stand age and development, which may be due to environmental conditions of the area: like nutrients availability and water in the soil. $\mathrm{Na}\left(0.35\right.$ and $\left.0.30\left(\mathrm{mg} \cdot \mathrm{l}^{-1}\right)\right)$, Ca $\left(1.57\right.$ and $\left.1.56\left(\mathrm{mg} \cdot \mathrm{l}^{-1}\right)\right) \mathrm{Mg}(0.32$ and 0.31 $\left(\mathrm{mg} \cdot \mathrm{l}^{-1}\right)$ ) contents in D. crassiflora leaf litter were significantly different in 2016 and 2017, but low concentrations of these mineral base elements do occur well in this ecosystem. Though Ogbonna et al. (2010) reported that, the content of base elements (K, Na, Ca and P) were relatively higher in pure Gmelina arborea stand in Umuahia, Abia State Nigeria.

The concentrations of $\mathrm{Cl}(0.25$ and 0.24$)\left(\mathrm{mg} \cdot \mathrm{l}^{-1}\right)$, Fe (0.94 and 0.94) (mg. $\left.\mathrm{l}^{-1}\right)$ and $\mathrm{pH}(1.19$ and 1.18$)$ values contents in $D$. crassiflora leaf litter from January 
to December in 2016 and 2017 respectively were relatively similar, but very low. The low contents of these mineral elements could equally be attributed to the stand age of the species, substrate quality and as well as site factors of the leaf litters. It is an established fact that tree in any ecosystems lead to soil changes through the chemical composition of foliage, quality and quantity of litter and the rate of litter (Nwaigbo, 2004). The mean $\mathrm{pH}$ values (1.19 and 1.18) of $D$. crassiflora leaf litter within the range are known to be strongly acid. Mangesh et al. (2019) observed that, pH values of leaf litter of different plant species ranged between 2.13 to 4.31 . The $\mathrm{pH}$ values of any leaf litter within this range seem to be mostly acidic in nature. According to Ogbonna et al. (2010) fallow soil and it litters had high levels of base content $(\mathrm{Ca}, \mathrm{Mg}$ and $\mathrm{Na}$ ) that raised the $\mathrm{pH}$ of the soil relative to the Gmelina plantation. The retention of improve bush fallow which have high capacity of nutrient contents through leaf litter in south-eastern Nigeria had proved to reduce soil acidity through release of $\mathrm{Ca}, \mathrm{Mg}$ and $\mathrm{Na}$ from fallow leaf litter (Ogbonna et al., 2010).

The mean concentration of Org. C (0.28 and 0.24) $\left(\mathrm{mg} \cdot \mathrm{l}^{-1}\right)$, Org. M (0.39 and 0.36) (mg. $\left.\mathrm{l}^{-1}\right)$, Cd (0.03 and 0.03) $\left(\mathrm{mg} \cdot \mathrm{l}^{-1}\right)$ and $\mathrm{Pb}\left(1.17\right.$ and 1.18) (mg. $\left.\mathrm{l}^{-1}\right)$ contents of D. crassiflora leaf litter from January to December in 2016 and 2017 were significant different, despite low nutrient contents. Org. C and Org. M contents in this study are in same range with the work of Ogbonna et al. (2010) who noted Org. C (0.970) and Org. M (0.560) Gmelina arborea, while Ekpendu (2003) recorded Org. C (43.51 mg. $\left.\mathrm{l}^{-1}\right)$ and high level of Org. M contents on Irvingia wombulu species. Nutrient accretion to the soil is primarily through leaf litterfall and decomposition. Organic matter breakdown in the tropical ecosystem such as Nigeria is rapid and aid in plant litter decomposition, which later return nutrients to the forest soil/floor. Consequently, heavy metals like Cd and $\mathrm{Pb}$ were also present in the leaf of $D$. crassiflora leaf litter though at low quantity. This implies that the environment which $D$. crassiflora species was established is polluted due to anthropogenic activities.

\section{Conclusion}

D. crassiflora leaf litter plays an important role within the nutrient cycle by replacement of various mineral nutrients to the forest soil/floor between January and December in 2016 and 2017. The concentration of both macro and micro elements was observed throughout different months and years of study with little disparity in terms of nutrient contents. The variability among these mineral elements within period of study (2016 and 2017) shows that there were no unique months (dry season and rainy season) that the concentration nutrients in the leaf litter of $D$. crassiflora were remarkable than others. The study shows uniform distribution of mineral elements contents in 2016 and 2017.

\section{Conflicts of Interest}

The authors declare no conflicts of interest regarding the publication of this paper. 


\section{References}

Alika, J. E. (2006). 2.13 to 4.31. The pH of Leaf Litter of Peepal Seem to be Mostly Acidic in Nature Compared to Other Statistical and Research Methods (2nd ed.). Benin City: Ambik Press.

Allison, F. E. (1973). Soil Organic Matter and Its Role in Crop Production. New York: Elsevier Publishers.

Ananthakrishnan, T. N. (1996). Forest Litter Insect Communities. Biology and Chemical Ecology. Science Publishers Inc.

AOAC (1990). Official Methods of Analysis Association of Analytical Chemists. Washington DC: AOAC.

APHA (1995). Standard Methods of Examination of Water and Waste Waters (18th ed.). Washington DC: America Public Health Association (APHA).

Ariwaodo, J. O. (2017). Personal Communication.

Binkley, D., \& Giardina, C. (1998). Why Do Tree Species Affect Soils? The Warp and Woof of Tree Soli Interactions. In N. Van Breemen (Ed.), Plant-Induced Soil Changes: Processes and Feedbacks (pp. 89-106). Springer. https://doi.org/10.1007/978-94-017-2691-7_5

Black, C. A. (1965). Methods of Soil Analysis. Madison: America Society of Agronomy. https://doi.org/10.2134/agronmonogr9.1

Bray, R. H., \& Kurtz, L. T. (1945). Determination of Total Organic and Available Source of Phosphorus in Soil. Soil Science, 59, 39-46. https://doi.org/10.1097/00010694-194501000-00006

Broadbent, F. A. (1965). Carbon Organic. In C. A. Black (Ed.), Methods of Soil Analysis (pp. 1397-1400). American Society of Agronomy.

Côté, B., \& Fyles, J. W. (1994). Nutrient Concentration and Acid-Base Status of Leaf Litter of Tree Species Characteristic of the Hardwood Forest of Southern Quebec. Canadian Journal of Forest Research January, 24, 192-196. https://doi.org/10.1139/x94-027

Dewis, J., \& Freita, F. (1970). Physical and Chemical Methods of Soil and Water Analysis. FAO Soils Bulletin, No. 10, 275 p.

Dicko, M. S., \& Sikena, L. K. (1992). Fodder Trees and Shrubs in Range and Farming Systems in Dry Tropical Africa. In A. Spesdy, \& P. Pugliese (Eds.), Legume Trees and Other Fodder Trees as Protein Source for Livestock (pp. 27-41). FAO.

Ekpendu, O. (2003). Litter Production and Nutrient Cycling in an Irvingia wombulu/Cocoyam-Based Agroforestry Ecosystem. Master's Thesis, Department of Forestry and Environmental Management, MAUOU.

González, I., Sixto, H., Rodríguez-Soalleiro, R., \& Oliveira, N. (2020). Nutrient Contribution of Litterfall in a Short Rotation Plantation of Pure or Mixed Plots of Populus alba L. and Robinia pseudoacacia L. Forests, 11, Article No. 1133. https://doi.org/10.3390/f11111133

Guckland, A., Jacob, M., \& Flessa, H. (2009). Acidity, Nutrient Stocks, and Organic Matter Contents in Soil of a Temperate Deciduous Forest with Different Abundance of European Beech (Fagus sylvatica L.). Journal of Plant Nutrition and Soil Science, 172, 500-511. https://doi.org/10.1002/jpln.200800072

Hasanuzzaman, M. D., \& Hossain, M. (2014). Leaf Litter Decomposition and Nutrient Dynamics Associated with Common Horticultural Cropland Agroforest Tree Species of Bangladesh. International Journal of Forestry Research, 2014, Article ID: 805940. https://doi.org/10.1155/2014/805940

Jackson, M. I. (1962). Soil Chemical Analysis. Prentice-Hall. 
Jeong, J., Lee, I. K., Lee, J. H., \& Kim, C. (2015). Nutrient Dynamics by Decomposing Leaf Litter at the Guemsan (Mt.) Long-Term Ecological Research Site, Korea. Forest Science and Technology, 11, 97-103. https://doi.org/10.1080/21580103.2014.966863

Keay, R. W. J. (1959). An Outline of Nigerian Vegetation (3rd ed.). Federal Ministry of Information.

Kumar, D. S., Prasad, R. M. V., Kioshore, K. R., \& Rao, E. R. (2012). Effect of Azolla (Azolla pinnata) Based Concentrate Mixture on Nutrient Utilization in Buffalo Bulls. Indian Journal of Animal Research, 46, 268-271.

Longman, U. A. (2007). Litter Decomposition, Nutrient Contents and Nutritive Values of Leaves of Three Bush Fallow Species in Umudike, Nigeria. Department of Forestry and Environmental Management, Michael Okpara University of Agriculture.

Mangesh, M., Arnab, B., \& Debnath, P. (2019). Variation of Nutrient Level in Soil and Leaf Litter of Selected Tree Species: A Case Study. Journal of Economic Literature (JEL) Classification, Q570, 100-111.

Marschner, H. (1995). Mineral Nutrition of Higher Plants (889 p). Academic Press.

Nwaigbo, L. C. (2004). Agroforestry: A Pathway for Soil Fertility Improvement and Sustainable Agriculture in Nigeria. In A. Afamdi, \& L. C. Nwaigbo (Eds.), Issues in Sustainable Agriculture in Nigeria (pp. 168-175). Osprey Publication Centre.

Ogbonna, P. C., Nzegbule, E. C., \& Tembe, E. (2010). Litter Quantity and Soil Characteristics of Gmelina arborea and Bushallow in Umuahia, Abia State, Nigeria. In FAN Conference (pp. 175-180).

Palm, C. A. (1995). Contribution of Agroforestry Trees to Nutrient Requirements of Intercropped Plants. In F. L. Sinclair (Ed.), Agroforestry: Science, Policy and Practice (pp. 105-124). Springer. https://doi.org/10.1007/978-94-017-0681-0_5

Reich, P. B., Oleksyn, J., Modrzyski, J. et al. (2005). Linking Litter Calcium, Earthworms and Soil Properties: A Common Garden Test with 14 Tree Species. Ecology Letters, 8, 811-818. https://doi.org/10.1111/j.1461-0248.2005.00779.x

Schroth, G. (2003). Decomposition and Nutrient Supply from Biomass. In G. Schroth, \& F. L. Sinclair (Eds.), Tree, Crops and Soil Fertility, Concepts and Research Methods (pp. 131-150). CABI Publishing.

Steel, R. G. O., \& Torrie, J. A. (1980). Principles and Procedures of Statistics: A Biometrical Approach. McGraw-Hill.

Vesterdal, L., Schmidt, I. K., Callesen, I., Nilsson, L. O., \& Gundersen, P. (2008). Carbon and Nitrogen in Forest Floor and Mineral Soil under Six Common European Tree Species. Forest Ecology and Management, 255, 35-48. https://doi.org/10.1016/j.foreco.2007.08.015

Wood, M. (1995). Environmental Soil Biology(2nd ed.). Springer. https://doi.org/10.1007/978-94-011-0625-2 